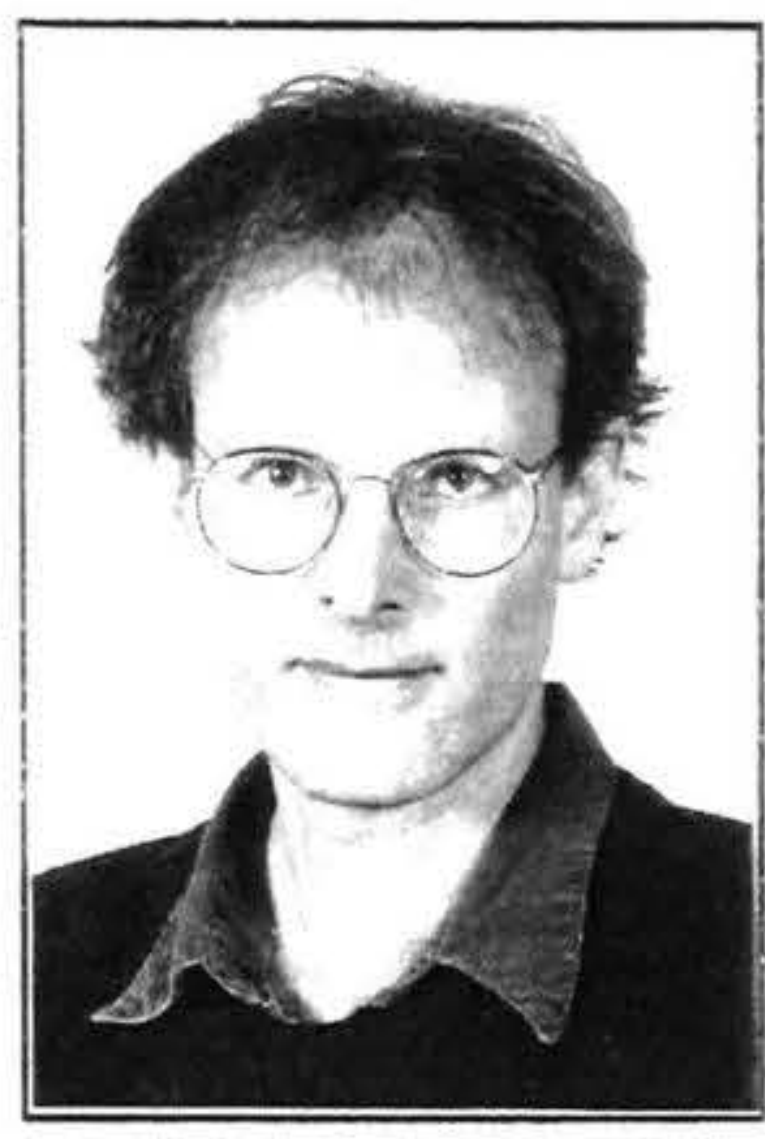

\title{
FAMILIES AND PATTERNS OF WORK: PAID AND UNPAID \\ PARENTAL LEAVE IN TWO PARENT FAMILIES
}

\author{
Paul Callister
}

Independent Researcher

\begin{abstract}
In a two parent family the birth of a child often results in one parent moving out of paid work for some period of time. This absence from paid work can come about through the use of formal parental leave, resignation from a job, or because the parent already may not be in paid work through unemployment or alternatively because they are already at home looking after older children. Using 1991 census data this paper examines the paid work patterns of parents in the first five years of a child's life with a particular emphasis on the first 24 months. The paper analyses these patterns using a range of parental characteristics including gender, education, occupation and ethnicity. The paper then examines the effect the introduction of paid parental leave may have on some of these patterns using the experience of Sweden. In particular, there is a focus on whether paid leave increases the number of men in the role of primary caregiver in the early years of a child's life.
\end{abstract}

In two parent families the birth of a child usually leads to substantial changes, sometimes short term but often long term, in the labour market behaviour of one, or sometimes both, parents. ${ }^{1}$

It is clear from numerous studies that women, in general, still have the main responsibility for looking after children in the first years of their lives, and also that men continue to have the main responsibility for earning family income (Podmore, 1994). However economic, and in some cases social, changes have placed a significant number of men in a variety of new situations. For instance, some men may be the primary caregiver while their partners are the primary income earner, while in other situations both parents are out of paid work when the children are young (Callister, 1994).

This paper is divided into two parts. In the first part New Zealand census data is used to examine the characteristics of partnered mothers who are in paid work in the first two years of a child's life. In addition, again using census data, there is an investigation of the characteristics of fathers of pre-school children who are not in paid work.

In the second part the issue of paid parental leave and fathers' involvement in childcare is examined. In New Zealand there is statutory provision of up to one year's unpaid leave, although in some individual workplaces paid leave may be available. Using Sweden as the main example, the paper examines whether the statutory provision of paid parental leave would be likely to increase the number of men who are primary caregivers.

\section{Mothers in paid work with children under two years of age}

Potentially the census gives an accurate count of the number of partnered mothers who are in paid work by the age of their youngest child. However, the wording of the question in relation to parental leave creates some problems. In the 1991 census a person is asked whether they work in a job, and also how many hours they worked in the last week. However, if the person did not actually work in the previous week they are asked to record their usual hours. It is difficult to assess how a person on parental leave would answer this question. It is likely that some may state that they are in paid work and record their normal hours before starting the parental leave.

According to the 1991 census $11 \%$ of partnered mothers with a child under one month old are in full-time work, and a further $11 \%$ of these women are in part-time work. Figure 1 indicates that the proportion of partnered mothers working both full-time and part-time rises steadily over the first two years of a child's life. It also indicates that the involvement of these women in part-time work increases at a slightly faster rate to reach $21 \%$ at 12 months and $25 \%$ at two years, while the full time figures are $14 \%$ and $17 \%$ respectively.

In a United States context, Klerman \& Leibowitz (1994) argue that as women's time away from the workplace has shrunk, understanding the changes in behaviour within the first year after the birth has become more important. ${ }^{2}$ They go on to suggest that conventional labour force participa- 
Figure 1. Partnered mothers participation in the labour force by age of youngest child, 1991

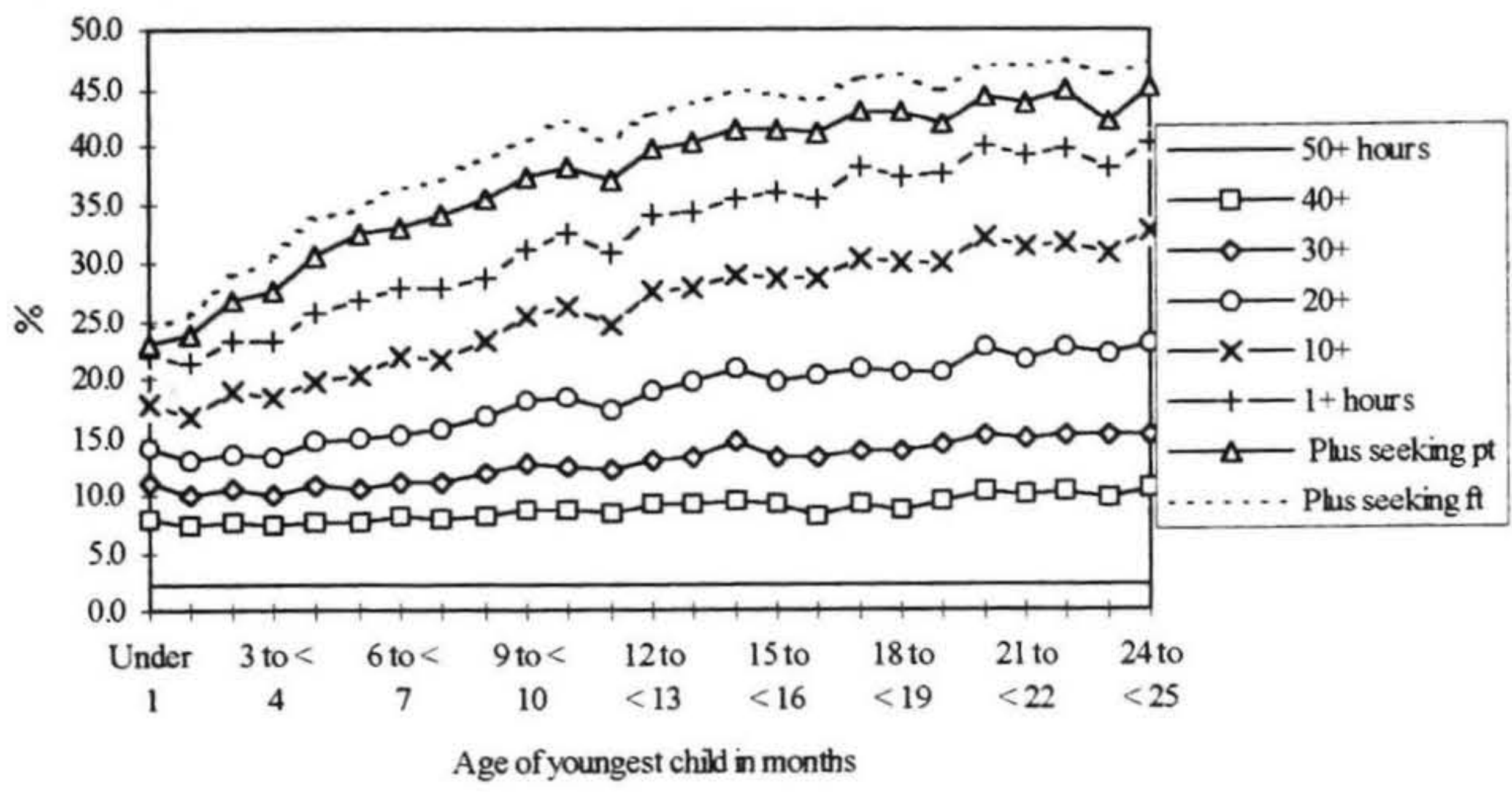

Source: The Census, Statistics New Zealand

tion measures can be misleading as a significant number of mothers are employed, but in the early months of a child's life are on leave, either on a paid or unpaid basis. Their data shows that in the first months of a child's life while $38 \%$ of the mothers are counted as being in paid work, only $10 \%$ of mothers are actually back working. The other $28 \%$ are on some form of paid or unpaid leave.

In New Zealand, data taken from the question regarding the person's main means of travel to work on the day of the census, a Tuesday in March, suggests that a significant proportion of mothers, who stated they were in paid work were in fact on parental leave. Overall $7.6 \%$ of women aged 15 and over, in full-time work, stated they "did not go to work today". But $52 \%$ of partnered mothers in full-time work with a child under one month did not go to work. At one month the figure is $41 \%$, two months $32 \%$ and three months $27 \%$. For part-time work the differences are not so marked with $26 \%$ of all women not going to work that particular day when working part-time, and $41 \%$ not at their part-time work with a child under one month.

Figure 2 shows that mothers with university qualifications are three times more likely to be in paid work with a child under one month old than mothers with no qualifications. This applies to their participation in both full-time and part-time work. However, as indicated, some of these women may be on parental leave, particularly as Klerman \& Leibowitz (1994) found that women with high levels of training were more likely than other women to be employed, but not actually at work, in the early months of a child's life.

The occupational profiles of mothers with children under

Figure 2. Percentage of partnered mothers in paid work by highest qualification and age of youngest child 1991

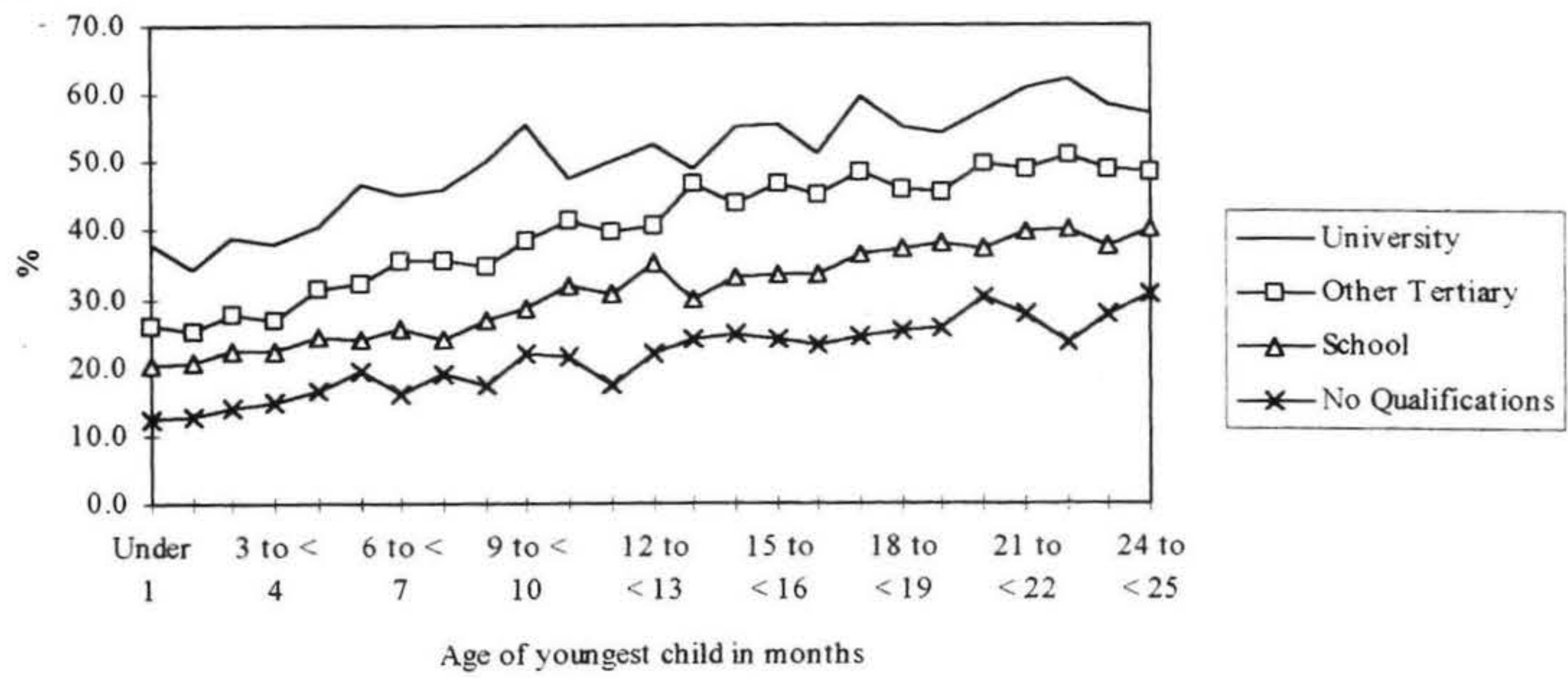

Source: The Census, Statistics New Zealand 


\begin{tabular}{|c|c|c|c|}
\hline Part-time & Full-time & Total part-time & Total full-time \\
\hline $\begin{array}{l}\text { Youngest child } \\
\text { Under } 3 \text { months }\end{array}$ & $\begin{array}{l}\text { Youngest child } \\
\text { Under } 3 \text { months }\end{array}$ & & \\
\hline
\end{tabular}

\begin{tabular}{lrrrr}
\hline \multicolumn{5}{c}{ Percentage } \\
\hline $\begin{array}{l}\text { Legislators, administrators and } \\
\text { managers }\end{array}$ & 8.3 & 11.0 & 4.1 & 10.7 \\
Professionals & 17.4 & 21.1 & 12.7 & 15.8 \\
Technicians \& associate & 12.1 & 10.7 & 7.6 & 11.5 \\
professionals & & & & \\
Clerks & 25.5 & 20.2 & 25.1 & 28.2 \\
Service \& sales workers & 11.6 & 8.1 & 27.5 & 14.4 \\
Agriculture \& fishery workers & 14.1 & 17.1 & 7.4 & 6.3 \\
Trades workers & 2.5 & 1.4 & 1.0 & 1.7 \\
Plant \& machine operators \& & 1.0 & 4.5 & 3.0 & 5.9 \\
assemblers & & & & 4.0 \\
Elementary occupations & 4.0 & 2.5 & 9.3 & 1.5 \\
Not specified & 2.3 & 3.4 & 2.3 & $\mathbf{1 0 0 . 0}$ \\
Total & $\mathbf{1 0 0 . 0}$ & $\mathbf{1 0 0 . 0}$ & $\mathbf{1 0 0 . 0}$ & \\
\hline
\end{tabular}

Source: The Census, Statistics New Zealand

three months of age when compared with those of all women in paid work also highlights some important differences, table 1. For mothers with young children, as would be expected from Figure 2, the profile is skewed towards occupations which generally require higher levels of formal education such as managers and professionals, but also towards those in agriculture and fishery occupations. This latter group includes farmers who may be able to better combine childcare with paid work than some other occupations. Sales and service workers are particularly under-represented amongst mothers of young children. These occupational differences diminish as the age of the youngest child increases.

The over-representation of mothers with young children in managerial and professional occupations is also connected to the age characteristics of these women. The proportion of mothers with a child under one who are in paid work increases with the age of the mother, although sharply declines for mothers who are fifty years of age or over. In addition, women in the forty-plus age group are more likely to work full-time rather than part-time.

A range of factors influence whether a partnered mother takes a period of leave, whether formal or informal, from paid work in the first years of a child's life, as well as the length of this leave. Currently, a wide range of intersecting factors such as the ethnicity of both parents; their levels of education; their age; the state of the job market; whether the mothers breastfeed; the number of children; income and occupation of the fathers; the availability and cost of childcare and familial and societal belief systems all influence this decision (Statistics New Zealand, 1994). The availability of paid parental leave would provide another important influence in this decision making process.

The overall proportion of women in paid work in New Zealand is lower than either the United States of America and Sweden. In New Zealand $63.8 \%$ of women in the 1564 age group were in paid work in 1990 while in the same year, according to the OECD, the figure for Sweden was $83.5 \%$ and the United States $69.6 \%$ (Statistics New Zealand, 1993). However, the patterns are more diverse for partnered mothers with under one year olds. Despite the high overall participation rates of these women in paid work in Sweden, paid parental leave as well as other family policies and social norms have created a situation where relatively few mothers are acutally back at paid work in the first year of a child's life. ${ }^{3}$ Yet in the same year $69 \%$ of those mothers with children in the one to three age group were in paid work (Näsman, 1990). In contrast in the United States, a country in which there is a much lower overall labour force participation rate of women in paid work than Sweden, $40 \%$ of mothers are actually back at their workplaces by the time a child reaches four months of age (Klerman \& Leibowitz, 1994). New Zealand contrasts with both countries with, in $1991.27 \%$ of partnered mothers in paid work when their children were under one, while this figure rose to $41 \%$ when children were in the one to three age group.

\section{Fathers not in paid work with pre-school children}

Between 1986 and 1991 there was a dramatic increase in the unemployment of men in New Zealand, including fathers of young children. Figure 3 highlights the 
Figure 3. Percentage of fathers not in paid work by ethnicity of both parents - youngest child under five - 1991

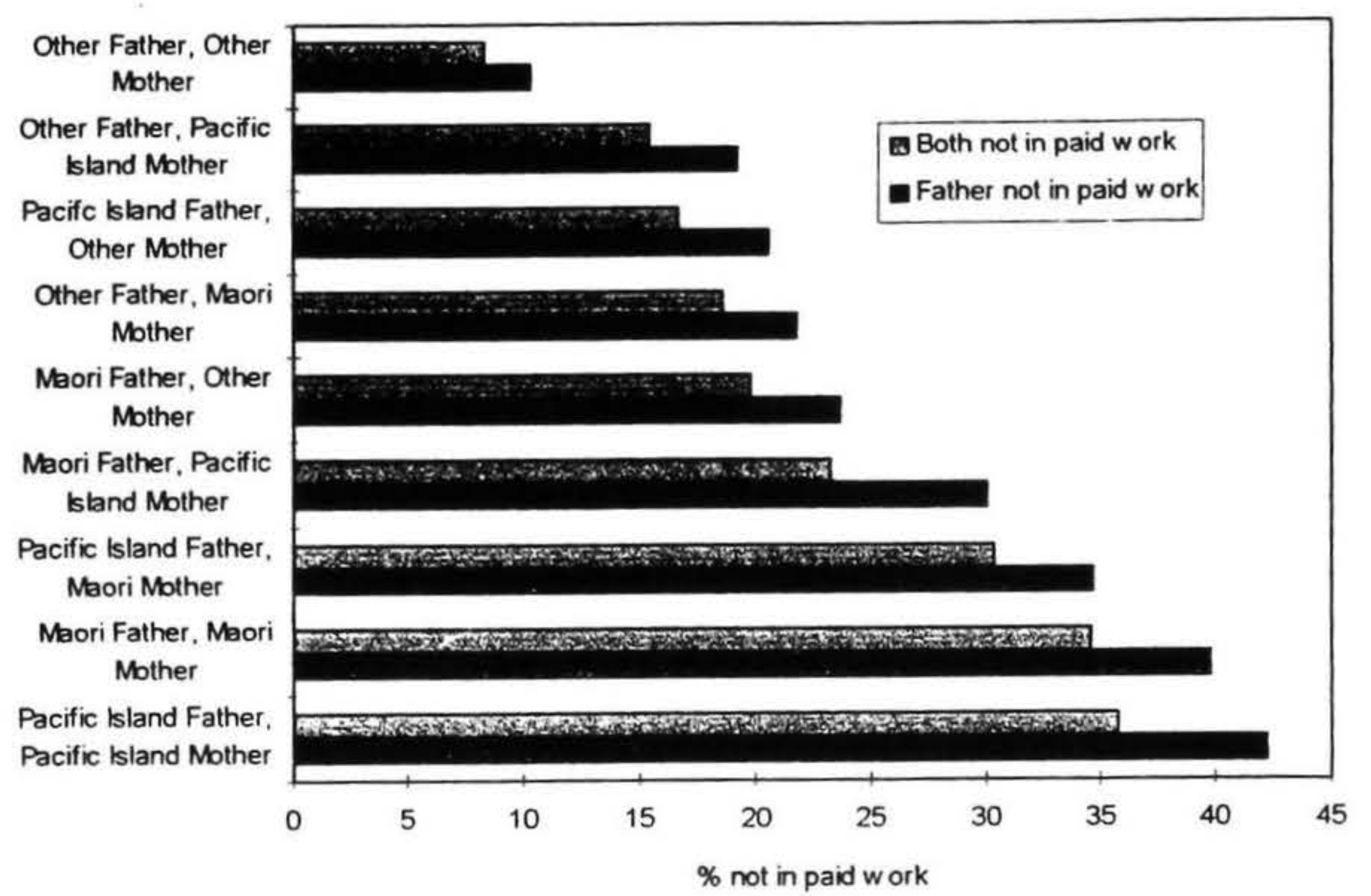

Source: The Census, Statistics New Zealand

particularly high proportion of partnered fathers within Maori and Pacific Island families who were out of work. But this chart also shows that in the majority of families where the father is not in paid work the mother also does not have paid work, a situation which is not unique to New Zealand (Davey \& Callister, forthcoming).

Some of these fathers will be unemployed for a short period, but $40 \%$ of those not in paid work were in the "nonlabour force' category, indicating that they may be out of paid work in the longer term. ${ }^{4}$ Three ethnic groupings account for just over $80 \%$ of families with fathers out of paid work when a child is under five.

Three main patterns are highlighted in table 2. Firstly, the proportion of men not in paid work decreases with the age of the child, which means children are most likely to have their fathers at home full-time when they are very young. The opposite trend occurs with those men whose partners have hours of paid work more typical of men than women. If a high proportion of these fathers are primary caregivers this may indicate that families think that fathers, for a variety of reasons, are less suited to looking after babies and toddlers than older children. This is an important issue when thinking about the use of parental leave, particularly in the early stages of a child's life. But the table also indicates that, despite the high unemployment of men, very few are likely to have become the primary caregiver of the children.

Analysis of census data at a more aggregate level, but using the activities question (Question 20 ) of looking after children at home', supports these general trends (Callister, 1994). This analysis also indicates that fathers who are unemployed, and the sub group who are possibly primary caregivers, are likely to have relatively low levels of qualifications. However low levels of qualifications are also linked to low positive responses to the childcare activities question. In general, the mothers in these families also have low levels of qualifications making it difficult for them to find paid work (Davey \& Callister, forthcoming).

\section{Fathers and paid parental leave}

In New Zealand statutory provision for parental leave are contained in the Parental Leave and Employment Protection Act 1987. This provides for 14 weeks matemity leave, two weeks patemity leave and extended leave for up to a year. The extended leave can be taken by the mother or her spouse. Unlike many industrialised countries there is currently no statutory provision for paid leave, however, over the last decade a number of proposals have been put forward to bring in some form of payment.

One of the arguments put forward for paid parental leave is that it might encourage the concept of a shared family responsibility for the care of the children, with men given the opportunity to step out of the role as primary income earner. For example, the Labour Party suggest that the:

current system encourages the 'men as breadwinner' mentality, which has the effect of encouraging women to stay at home. By not offering wage replacement, men are less likely to take leave because they are seen as the breadwinner. The wage gap between men and women contributes to this because the family will generally be better off if the father stays at work. (Labour Party, 1994:6) 


\begin{tabular}{|c|c|c|c|c|c|}
\hline & \multicolumn{2}{|c|}{ Age of youngest child } & \multirow[b]{2}{*}{2 years } & \multirow[b]{2}{*}{3 years } & \multirow[b]{2}{*}{4 years } \\
\hline & Under 1 & 1 year & & & \\
\hline \multicolumn{6}{|l|}{ Maori father, Maori mother } \\
\hline$\%$ of fathers not in paid wok & 43.6 & 41.4 & 37.3 & 37.6 & 34.2 \\
\hline $\begin{array}{l}\% \text { of fathers not in paid work and where } \\
\text { mother works } 40+\text { hours per week }\end{array}$ & 1.8 & 2.3 & 2.8 & 3.3 & 3.4 \\
\hline \multicolumn{6}{|l|}{ Pacific Island father, Pacific Island mother } \\
\hline$\%$ of fathers not in paid work & 45.4 & 43.2 & 41.3 & 37.9 & 37.5 \\
\hline $\begin{array}{l}\% \text { of fathers not in paid work and where } \\
\text { mother works } 40+\text { hours }\end{array}$ & 2.6 & 3.6 & 3.8 & 5.5 & 5.7 \\
\hline \multicolumn{6}{|l|}{ Other father, other mother } \\
\hline$\%$ of fathers not in paid work & 11.4 & 10.6 & 9.8 & 9.4 & 9.2 \\
\hline $\begin{array}{l}\% \text { of fathers not in paid work and where } \\
\text { mother works } 40+\text { hours }\end{array}$ & 0.5 & 0.7 & 0.9 & 0.9 & 0.9 \\
\hline
\end{tabular}

Source: The Census, Statistics New Zealand

The campaign for twelve weeks paid parental leave argues that the payment should be set at $100 \%$ of earnings, although limited to the average male wage. They suggest that this payment rate would encourage more men to take up child-rearing responsibilities because it allows the family to choose what is best for them, rather than being constrained by which parent is earning more.

Sweden contrasts with New Zealand in that it has very generous paid parental leave provisions. In addition, official policies have been directed at encouraging men to take an equal share of household work, including childcare.

This interest in men and their work in the private sphere is a distinctive feature of Swedish equal opportunities policy. As far back as 1968 the $S$ wedish government presented a report to the United Nations Economic and Social Council arguing that role sharing in the family was a prerequisite for women's full participation in the economy, politics, and trade unions. Sandqvist (1992) argues that most Swedes saw it as unacceptable that women might only achieve equality in paid work by relying on domestic help to replace them in the home. The successful struggle for class equality had made the bourgeois life-style, dependant on maids for domestic work, both ideologically unacceptable and economically unfeasible. This interest in both gender and class equality of the 1960 s was developed by the appointment of a special committee in 1972 to make recommendations on measures to increase equality between men and women as well as the introduction of Parental Leave in 1974 (Rapoport \& Moss, 1990).

The Swedish Act of Equality which is intended to promote equal rights between women and men at work, recognises that this equality also requires changes in parenthood. It states that equality means that men not only need to take responsibility for both children and the work of the household under the same conditions as women, but also that women and men have equal rights to children (Rapoport \& Moss, 1990).
In Sweden fifteen months of paid parental leave is available to either parent following the birth of a child. The level of benefit is $90 \%$ of earnings for 12 months with a cap on benefits for higher income earners and a fixed allowance for the latter three months (Labour Party, 1994)

However paid parental leave is only one feature of an overall set of policies aimed at assisting parents balance work and childcare commitments in Sweden. These policies embody a very clear idea of what is seen as being good for child development and health. When children are very young, less than twelve to eighteen months, it is expected that a parent should be at home (Rapoport \& Moss, 1990). Childcare outside the home is regarded as good for children over twelve to eighteen months as long as the hours are not excessive. It is accepted that there needs to be a balance between work and family life, and also that it is important for parents to have equal access to good quality childcare. It is also widely accepted that work-family issues are social issues for which the government has a major responsibility (Rapoport \& Moss, 1990).

As part of this overall philosophy other employment entitlements are available for parents. These include:

* 50 days pregnancy leave

* 10 days paternity leave

* 90 days leave per year per child under 12 to care for a sick child or to care for a child if his/her normal caregiver is ill

* 2 days leave per year to visit a child's nursery or school

* the right to work a six-hour day until a child is eight

All except the last entitlement are compensated from social insurance at $90 \%$ of gross earnings.

Some important features of the Swedish parental leave system are its flexibility, its high level of payments and the fact that this payment is available for a substantial period of time (European Commission, 1993). In terms of flexibility parents can take part or all of their paid leave on a 
full-time, half time or quarter time basis. They can take leave in one block of time or several, transfer leave between parents or switch from full-time to part-time leave or vice versa, the sole constraint being that only three changes can be made per year. Finally, parents have flexibility in how they claim and use this allowance.

Fathers have a mixed pattern of using these benefits. In terms of paternity leave $83 \%$ of fathers used an average of nine of these days in 1987 while more than half of all fathers used all ten days (Näsman, 1990).

In terms of using temporary parental allowance, to look after a sick child for instance, in $198741 \%$ were men, and they used 35\% of the allotted days (Näsman, 1990).

The proportion of $S$ wedish men utilising parental leave has increased from $3 \%$ in 1974, when parental insurance was introduced. The increase took place mainly in 1978, when parental leave was extended from six to eight months with full parental allowance. In 1989/90 50\% of fathers had taken some leave by the time their children were over 15 months of age (European Commission, 1993).

Fathers are more likely to take leave as children get older. In 1989/90 the proportion of fathers taking leave increased from $21 \%$ for children under six months, to $35 \%$ for children aged nine to eleven months with $50 \%$ of men taking leave when their children were over 14 months. One third of fathers taking parental leave make use of the flexibility of the system, for example taking short periods of leave or part-time leave. However, men take significantly fewer days than women. In 1989, fathers taking some leave during the child's first year averaged 43 days away from work compared to 262 for mothers, with these figures being similar to those of the early 1980 s (European Commission, 1993).

So what stops men taking parental leave, especially in the first six months ? Näsman (1990) provides a summary of Swedish language literature. Factors influencing the uptake include the fact that most mothers breastfeed until at least six months; some women in monotonous jobs prefer to be home; some women did not want their partners to share the work; some families, despite the attempt to make the benefits equal, felt it was more financially advantageous for the man to be in paid work; and also some men reported facing negative attitudes in the workplace. Hwang (1987) notes that employers, particularly those in the private sector, are often negative to men staying home with children. In his study he found that about half of the supervisors, and about a quarter of workmates, had negative reactions to a man taking parental leave. Workmates in organisations where women outnumbered men were decidedly more in favour of the father taking parental leave than those in male dominated workplaces.

On the other hand, what are the factors which encourage men to take parental leave and what are the characteristics of the men who take it? Näsman (1990) notes a number of findings in the Swedish language literature which suggest that men are not only more likely to take leave if another man at the workplace has already done so but also if they are salaried and employed in the public sector. In addition, most men approve of parental leave for men but often feel that colleagues and, in particular, supervisors do not share this view. However, Näsman also cites two studies in which it was uncommon for men to refrain from taking parental leave on account of negative attitudes in the workplace. Rapoport and Moss note that while in general men take far less parental leave than women, high level employees, including women, are not high users of parental leave. They also suggest that there is a concern among some employees that taking large amounts of leave will affect their careers. It is possible these fears may increase with the recent rise in unemployment in Sweden

The fact that in Sweden high level employees take little parental leave initially seems in conflict with Sandqvist's (1987) suggestion that the level of fathers' education is positively related to fathers taking parental leave. However, research in Norway which indicates that men with high levels of education, but middle range incomes, are the most common male users of parental leave may provide some explanation (European Commission, 1993).

Sandqvist also notes Swedish research which indicates that not only do those men taking parental leave rate higher on the social class index but also that white collar fathers experience their parental leave more positively than blue collar fathers. With regard to the former group Sandqvist suggests that this indicates a more internalised progressive sex-role ideology. However other factors may be at work such as where they live, their other resources, and the attitudes of peers. Sandqvist also notes a study in which it was found that the higher the mother's income the more likely the father is to take parental leave.

Studies in Norway and Denmark also suggest that the uptake of parental leave by men is more likely if both partners have above average levels of income and education. These factors usually indicate that both parents have strong bargaining power in the labour market and also that the mother has a stronger negotiating position in the family (European Commission, 1993). In addition, these studies confirm the idea that men are more likely to take leave from workplaces that are predominantly female, and also from those workplaces which are part of the public sector. Sundberg (1993) suggests the most important factor influencing fathers' uptake of parental leave is having a highly educated partner which is likely to not only give her a stronger and more permanent commitment to the labour market but also more liberal views about new family parterns and roles for parents.

It therefore appears that the upholding of 'egalitarian' attitudes, which is at times linked to higher education, may be a key factor in encouraging men to take parental leave.

Linked to education, it appears uptake of parental leave can, at times, be influenced by direct campaigns. For example, Rapoport and Moss cite a Trade Union implemented campaign among their members which resulted in an increased proportion of men taking leave. In New 
Zealand there are examples of organisations trying to support equal choice by men and women when it comes to taking parental leave (Glendining, 1992).

However, a Danish study provides a caution for researchers who focus simply on formal parental leave. It was found that fathers not using leave spent eight weeks at home during the child's first year, while those taking leave spent fourteen weeks, only part of which (five to six weeks) was parental leave. Many Danish fathers use holidays, time off in lieu or change their working hours, for example doing evening work, in order to extend their paternity leave and spend more time with their children (European Commission, 1993). Swedish research cited in the same report also suggests that some men take on shift work in order to spend more time with their children.

In general, it appears that in Sweden encouraging men to take on a more equal share of housework and childcare through a range of policies including paid parental leave has met with some limited success, and that the stresses on families, in particular women, of combining work and family life have been reduced (Haas, 1990; Sandqvist, 1992, Näsman, 1990). But while on an average hourly earning basis women now earn $90 \%$ of men's wages, and overall female participation in paid work is high, hours of paid work between men and women still vary considerably and women remain concentrated in a narrow band of occupations. Therefore they are still far from achieving equality in paid work (Sandqvist, 1992, Rapoport \& Moss 1990).

The Swedish studies were all carried out in a period when Sweden had very low rates of unemployment. However they highlight the fact that men who choose to take parental leave are usually well educated and have well educated partners, and are likely to have 'egalitarian' views. In contrast it is likely that the men who are at home with their children through unemployment, such as in New Zealand and the United Kingdom, have low levels of education, are with partners who similarly have low levels of education, and may often hold very 'traditional' values.

\section{Conclusion}

The way census data is collected provides an ability to analyse parents' participation in paid work from the first month of a child's life. However, it is not clear whether women who are classified as being in paid work are actually working or are on parental leave. It would be useful if this important difference was able to be identified.

In New Zealand involuntary unemployment, rather than being an active choice such as taking parental leave, appears to be the main reason behind the increase in men at home with their young children. Overseas literature indicates that children, and fathers, are better off if the father has made a positive choice to be home with them (Callister, 1994). This would indicate that the way in which New Zealand, by accident rather than by changing societal attitudes, has brought more fathers into contact with their children may have the potential to create prob- lems. The apparent increase in violence against children may be one of them. However, it also appears that some fathers have adapted well to this new role despite the lack of widespread societal support (Callister, 1994).

The data from Sweden suggests that having generous paid parental leave provisions, along with policies which encourage men to share housework and childcare equally with women, have some influence on men's involvement in childcare. But it is also clear that few men take extensive periods of parental leave, particularly in the first six months of a child's life. This suggests that even if campaigners are eventually successful in bringing in paid parental leave for twelve weeks in New Zealand, on its own such provision is likely to have little effect in terms oencouraging men to become primary caregivers or even equally sharing the care of young children.

\section{Future research}

A significant proportion of partnered Maori and Pacific Island men with young dependent children are not in paid work. Given past employment trends it is possible that even in the current period of economic expansion, mothers in these families will have more opportunities than the fathers to find paid employment. Little is known about the situation of these men, and especially how such families are adapting to the potential challenges to traditional roles.

It is also apparent from the $S$ wedish research that workplace attitudes have an important effect on the balance between work and family in men's lives. Not much is known about this in New Zealand, and it appears to be an area worth exploring.

Finally, little is known about the current use of parental leave in New Zealand. It is hoped that the Labour Department survey in progress will help expand our knowledge in this area. However, it also appears that it may be possible to frame existing questions in official surveys, such as the census, in a way which helps identify the use of parental leave, along with employment patterns of parents with very young children. Statistics New Zealand need to consider this when redesigning surveys.

\section{References}

Davey \& Callister 1994 Parents in paid work: The Workforce pattems of parents iwth children under five years of age. New Zealand Sociology, 9(2):216241

Callister, P. 1994 Fathers as primary caregivers in two parent families. Paper presented to the 1994 New Zealand Association for Research in Education, Christchurch, December 1-4

European Commission Childcare Network. 1993 Leave arrangements for workers with children: A review of leave arrangements in the member states of the European Community and Austria, Finland, Norway and Sweden. European Commission Network 
on Childcare and other measures to reconcile employment and family responsibilities Draft report, Brussels

Glendining, Danna. 1992 This motherhood lark - the Report of the study of parental leave taken from the New Zealand Customs Department 1987-1992. New Zealand Customs

Haas, Linda 1990 Gender equality and social policy: Implications of a study of parental leave in Sweden Journal of Family Issues 11 (4) : 401-23

Hwang, C.P. 1987. The changing role of Swedish fathers, in M, Lamb (ed), The father's role - Cross cultural perspectives Hillsdale, New Jersey :115-136

Klerman, Jacob Alex \& Leibowitz 1994. The workemployment distinction among new mothers $T$ The Journal of Human Resources 29 (2) : 277-303

Näsman, Elisabet 1990, The importance of family policy for fathers' care of their children. Paper presented at the Glasgow seminar 'Men as carers for children: report on an EC Childcare Network technical seminar' European Commission Childcare Network, Brussels

Paid Parental Leave Campaign - Information Kit. 1994. 12 Weeks: Information kit. Wellington

Podmore, Valerie N. 1994. Employment and childcare arrangements among families New Zealand Council for Educational Research, Wellington

Rapoport, Rhona \& Moss, Peter 1990 Men and women as equals at work Thomas Coram Research Unit Occasional Paper No 11, London, University of London

Sandqvist, K. 1987. Fathers and family work in two cultures - Antecedents and concomitants of father's participation in childcare and household work. Unpublished $P h D$ thesis, Almqvist and Wiksell International, Stockholm

Sandqvist, K. 1992 Sweden's sex-role scheme and commitment to gender equality in S.Lewis, D.P Izraeli, H. Hootsmans (eds) Dual earner families: International perspectives Sage, London

Statistics New Zealand. 1993 All about women in New Zealand. Statistics New Zealand, Wellington

Statistics New Zealand 1994. New Zealand Now: Families Statistics New Zealand, Wellington

Sundberg, E. 1993 A Dream and a Catalogue - paper given at seminar "Men as carers: Towards a culture of responsibilities, sharing and reciprocity between the genders in the care and upbringing of children" Ravenna, May 21.

Tennet, Elizabeth. 1994. Paid Parental Leave: $A$ discussion paper

\section{Notes}

${ }^{1}$ In addition either one or both parents may not have been in paid work prior to the birth of the child, through unemployment, or perhaps because they are already out of the labour force looking after an older child, in which case their labour force status does not change.

${ }^{2}$ This study covers all mothers not just those with partners.

${ }^{3}$ In 1989/9098\% of Swedish mothers took parental leave during the child's first year. Nearly half $(44 \%)$ took more than 271 days, while a third took between 181 and 270 days, with an average of 262 days (European Commission, 1993).

41986 definition of unemployed and seeking work

\section{Acknowledgements}

This research was funded by two grants from the Foundation for Research, Science and Technology. The overseas studies were identified through a literature search which is part of an ongoing joint project with the New Zealand Council for Educational Research on families, work and education.

\section{Author}

Paul Callister is an independent researcher, 88 The Parade, Paekakariki. 